This is a self-archived version of an original article. This version may differ from the original in pagination and typographic details.

Author(s): Tynjälä, Päivi; Newton, Jennifer M.

Title: Transitions to Working Life: Securing Professional Competence

Year: 2014

Version:

Copyright: ㄷ Springer Science+Business Media Dordrecht 2014

Rights: In Copyright

Rights url: http://rightsstatements.org/page//nC/1.0/?language=en

Please cite the original version:

Tynjälä, P., \& Newton, J. M. (2014). Transitions to Working Life: Securing Professional Competence. In S. Billett, C. Harteis, \& H. Gruber (Eds.), International Handbook of Research in Professional and Practice-based Learning (pp. 513-533). Springer. Springer International Handbooks of Education. https://doi.org/10.1007/978-94-017-8902-8_19 


\title{
Transitions to working life: Securing professional competence
}

\author{
Päivi Tynjälä (University of Jyväskylä) and Jennifer M. Newton (Monash University, Australia)
}

\section{Introduction}

This chapter examines the transition from education to work as a critical phase of professional career and the development of professional competence Literature on transition to working life has identified several challenges that many graduates meet in the early stages of their career such as: threat of unemployment, inadequate knowledge and skills, decreased self-efficacy and increased stress, instability of professional identity, newcomers' role and position in a work community, early attrition and changing occupation. The importance of workplace learning in supporting graduates as they transit to the workplace is influential in assisting graduates deal with these challenges. This chapter examines each of these challenges from the professional competence point of view drawing upon examples from several research projects undertaken by the authors to accentuate how these challenges might be addressed. In particular special attention is paid to the role of social partnerships in meeting the challenges.

Most of the studies pertaining to school-to-work transition have focused on the employment of newly qualified people (e.g. Teicher 2007; Betti, Lemmi \& Verma 2009). Comparisons between transition practices across countries have revealed substantial differences in how they provide workplaces for youth. However, qualitative analyses on circumstances beyond the cold figures are rarer. One exception is Guile's (2009) conceptual analysis in which he argues that the transition from education to work should be thoroughly rethought. According to him the transition should be understood as the development of vocational practice rather than acquisition of qualifications. This follows that the conceptions of vocational practice need rethinking as well and seeing vocational practice as "evolutionary, laterallybranching and envisioning”. In other words, vocational practice in this view involves creating new practices and objects as well as modifying and developing existing practices; and workplace pedagogies are central to these processes. This kind of conceptualizing of vocational practice entails the idea of vocational development as a continuum starting from education and continuing throughout one's working life, involving both vertical and horizontal transitions and transformations. It also entails the idea that transitions are not only individual phases of development, but also junctions that link individual and institutional processes (see Volanen, 2012).

The conceptualization of transitions to working life as the development of vocational practice and as junctions of individual and institutional processes, in turn, suggests a paradigm change in how the transitions are enacted. Two different approaches can be discerned in this respect: an individualistic approach that relies on developing individual attributes that help in transition (e.g. training career adaptability, Koen, Klehe \& van Vianen, 2012; or “newcomer socialization”, Saks \& Gruman, 2011) and an institutional approach which is based on building social partnerships between education and work (e.g. Billett \& Seddon, 2004; Deitmer \& Heinemann, 2009). In this chapter, our main focus is on the latter. In some vocational education and training systems partnerships between education and work have a long history. A well-known example is German dual VET system where industry and education sector jointly take care of apprenticeship training. In many other countries, VET partnerships have been developed only recently and are organized in a less structured way. For example, in Finland students' workplace learning is organized within the framework of national and local agreements between the education and industry partners. In recent years, there has been increasing interest in social partnerships across higher education institutions internationally to ensure that university graduates have the ability to make smooth transitions to into professional practice (Billett and Henderson, 2011). 
In the following sections, we examine the transition to working life from the professional competence point of view. We discuss the challenges of the threat of unemployment, inadequate knowledge and skills, decreased self-efficacy, instability of professional identity, newcomers' role and position in a work community, and the importance of workplace learning (cf. Tynjälä and Heikkinen, 2011). The specific role of social partnerships in relation to each of the challenges is discussed drawing upon, where relevant, empirical evidence from several research projects in the field of healthcare to provide insights into how the above challenges can be addressed. We argue that the role of social partnerships is central to understanding and responding to transitions issues. In particular, the presence of pedagogical arrangements with strongly aligned education and practice experiences seems essential.

\section{Challenges in school-to-work transitions}

\subsection{Threat of unemployment}

A study by Betti, Lemmi and Verma (2009) describes school-to-work transition in EU countries by analyzing the employment situation of individuals as a function of the time elapsed since the person's most recent exit from education or training in relation to the current employment situation. Their findings show big differences between the countries in overall employment situation and for the newly graduated in particular. The countries where the overall employment situation is poor (Spain, Italy, Greece) the disadvantage of the newly qualified group tends to be accentuated. During 2012, media reports indicated the unemployment rate of Spain being above $25 \%$ and more than half of young people being out of work. In general, the probability of unemployment seems to decrease as the level of education increases (e.g. OECD 2000; Woolbers 2000; see also Teichler 2007). However, in recent years the unemployment also among highly educated has been increasing in many countries (e.g. Moreau and Leathwood 2006; Livanos 2010). Therefore, the threat of not getting a job after schooling may be true not only for lowskilled workers, but also for highly educated. Indeed, recently in Australia there has been considerable concern raised from nursing's professional and union organisations that newly degree qualified nurses have been unable to secure employment in a graduate program with a health care organisation (White, 2013). This has significant employment implications for these new nurses as many non-graduate nursing positions advertised require a registered nurse who has a minimum of twelve months experience. Thus gaining a university qualification may, into today's competing workforce not necessarily guarantee a successful transition from school to work and it would appear that this might be influenced by unemployment rates. Betti et al.'s study (2009) showed that there are differences amongst countries in how the unemployment rate varies across education levels. For instance, Austria and Finland were characterized with high index of the overall employment situation of "juniors" (i.e. persons with the exitfrom-school-to-observation interval of up to 5 years), and the employment situation was quite equitable for persons with different levels of education/training. By contrast, in the UK and Ireland, also characterized by good overall employment situation of juniors, there were marked differences based on levels of education/training, meaning that the employment situation for poorly educated was much worse than for the better educated.

As noted above, here we discuss the challenges of school-to-work transition from the partnership point of view. From this perspective, the employment situation becomes very interesting case and the following question arises: Are there differences in employment rates between the countries with or without dual system style of in vocational and professional education and training? In other words, is the employment situation of young people better in the countries where vocational students are employed in apprenticetype situations during their education and training? This consideration is founded on the kinds of preparatory programs that include significant components of workplace According to Betti et al.’s (2009) 
study there was no clear-cut relationship between the type of vocational school system and the employment outcome. In European Union statistics (European Union, 2012), the lowest level of youth unemployment rates were found in the Netherlands, Germany and Austria of which the latter two have dual VET-system. (The lowest youth unemployment rate in Europe is in Switzerland, but it was not included in the statistics because it is not the EU member state). In OECD statistics from 2011 (OECD, 2012), the lowest unemployment rates among young people were in Switzerland, Netherlands, Japan, Austria and Germany. Thus, among the top performing five EU member, states the dominating vocational training type is based on the dual system in three countries, and on school-based system in two countries. The reason for the inconclusive findings may lie in the fact that there may be functional social partnerships also in these countries with the school-based VET-system. For example, in the Netherlands, there is a widespread use of work-based learning. Outside of the EU, within Australia for example, the VET system is informed by industry and is client-focused to deliver flexible, relevant and responsive education and training. Similarly in Finland, a work-based learning system was introduced as part of school-based vocational education and training at the beginning of the Millenium, with positive effects on vocational school graduates' employment (Tynjälä et al., 2006a). Although the phenomenon in question is complex in nature with complicated interrelationships between educational and labour market systems as well as societal conditions, the findings of their review suggest that close collaboration between vocational schools and workplaces is conducive to effective post-school transitions that lead to employment. The mechanisms behind this probably lie in the fact that partnerships provide students and employers with an interface to meet each other and thus make smooth transitions possible.

\subsection{Inadequate knowledge and skills}

When young people are facing the challenge of finding a job, they also often have a feeling that their education has failed to prepare them with adequate skills and knowledge for the working life (e.g. Crebert et al. 2004; Murtonen et al. 2008; Stenström 2006; Teichler 2007). For example, in a Finnish study university graduates after 2-10 years of work experience were asked where they had learnt the skills they required in their job. Of the respondents $(n=955) 66 \%$ thought that they had learnt the most important skills at work and only $14 \%$ mentioned university as the learning site of these skills (Tynjälä et al., 2006b). Research on newly qualified health professionals also clearly demonstrates graduates' concerns about a sense of lack of preparedness for the demands of their professional role. In a study by Newton and McKenna (2007) examining newly qualified nurses' experiences of their first few months in practice, participants reported lacking appropriate knowledge and skills. Thus, when they began their graduate program they did not feel prepared. Olivia, a new graduate nurse, illustrates this point well,

"Now I understand that I was not very prepared, I knew that I could probably get through the day. I could get patients showered and meds [medications to patients] given but if anything had gone wrong I don't think that I was prepared for any little hitch in my day".

This sense of unpreparedness, generates a lack of confidence in the graduate's competence in managing the reality of everyday practice as Cathy, another graduate, stated:

“Clinically I don't think that I felt ready...when you're out there doing it with very sick patients...very hard to um ... be prepared for that".

Research on doctors' transition from student to newly qualified doctor and transitions from generalist to specialist clinical practice highlights the complex kinds of learning that occurs in the reality of everyday practice as the novice acquires the competence to manage difficult and complex situations (Kilminster \& Zukas, 2013).To an extent, these feelings of inadequate competence in early phases of a career can be seen as a natural phase of professional development. Studies of expertise have consistently shown that the 
development from a novice to an expert takes about ten years (Feltovich et al., 2006). Keeping this is mind, it is not reasonable to expect that newly qualified employees would have high level expertise right in the beginning of their career. Rather, the slow development of expertise combined with the rapid change in society and the world of work suggest pursuit of the kind of professional development models that are based on the idea of continuum from initial professional training towards lifelong continuous professional development. From the education point of view, a worthwhile question related to skill development is what kind of educational practices are associated with expected learning outcomes. As the relationship between learning outcomes and their predictors is highly complicated there are only a few studies that have tackled this question. In a survey of more than 1200 Dutch graduates by Vaastra and Vries (2007) it was reported that graduates from highly activating learning environments (such as problem-based learning and project learning) attributed more generic and reflective competences to themselves than graduates from conventional learning environments. The findings also showed that learning ability, analytic competences, working independently and working in a team positively contributed to the development of competences in the later careers of graduates. As regards vocational education and training, Virtanen, Tynjälä and Eteläpelto (2012) examined factors predicting vocational students' learning outcomes during their workplace learning periods. The largest explanatory factor was the active membership. The more students reported that they were able to function as active members of their workplace (i.e. having the possibility to influence the way things were done at the workplace, with regular workers asking their opinion and advice and possibly learning from them) the higher they evaluated their skills learning and professional identity development. The second biggest factor explaining students' learning outcomes was the integration of experiences between school learning and workplace learning. This is an element of educational practices and it describes, at a very concrete level, the connection between the students' two different learning environments, the school and the workplace. The closer the students held the integration between school and workplace learning to be, the better were their (self-assessed) learning outcomes. The integration factors included variables describing features of integrative pedagogy (e.g. Tynjälä, 20008; Tynjälä \& Gijbels, 2012) such as discussing workplace learning situations at school, learning tasks from school to work, and applying knowledge learnt at school at work. The integration factors also contained variables referring to connective model of work experience described by Guile and Griffiths (2001).

Critical then to ensuring students perceiving they possess the necessary competences to function in their impending professional role is the pedagogical approaches utilized to foster the integration between the two learning environments, of school and the workplace. As a component of a larger project exploring preparation for practice for healthcare professional students, Newton (2011) examined how to enhance this integration between university studies and the clinical workplace with a group of final year undergraduate nursing students through a facilitated reflective learning group. Six students over a period of seven months met monthly and were encouraged to identify their own action points at the end of each learning group that would then be revisited the next time they met. The intent behind this was to encourage the students to develop a sense of personal empowerment and foster reflexivity and agency. Fenwick (2013, p.364) argues that education needs to "attune professionals to the multiple and complex nature of transitions - the shape of their personal transitional experience(s) in terms of the assemblages or practice, regulations, work arrangement, knowledge cultures in which their experience is unfolding”. Certainly, this was the educational process that the students in Newton's (2011) study experienced. The reflective learning group allowed for consideration of multiple perspectives of practice issues that students would not have necessarily undertaken without this guidance as they prepared for their transition to their professional role. The learning group provided a space in which the students were able to explore and challenge their previously held values and assumptions about professional practice, organizational cultures and demands, and expectations. This space enabled the students to consider how to work more independently and to recognize that they were not expected to 'know everything'. This is illustrated through Donna, a third - year nursing student, who shared the following insight: 
Realizing that I do know stuff, which I didn't think I did, I just think it's a confidence thing and having the support from the University is really important ... because I've had this wonderful start to this year, I'd be much more able to cope next time I think...

Through the sharing and drawing out experiences, the students perceived a reduction in fearfulness of being regarded as not having adequate knowledge if they asked others for advice. The reflective learning group provided a pedagogical process to develop the students' capacity to be better prepared for facing problems and simultaneously working out how to resolve problems or issues at the time. The students gained an awareness of how to create learning opportunities when working in clinical practice alongside a registered nurse, acknowledging how to indicate where their level of competence was at, as illustrated in the following quote:

I think it's okay to, tell the preceptor [a registered nurse] this is where I think I'm at and, and this is the level that I think I can perform to and then you know, that might be above what that preceptor thinks that I'm at, but they don't know me, so, but, if you tell them then, then they don't expect too little or too much.

During the seven months, as the students engaged in both university studies and clinical workplace practice, the students gained confidence that enabled their skills and theoretical knowledge to be refined into understandings about actual nursing practices as they learned how nurses might behave in the workplace- enabling integration of these views into a personalised model of professional practice. The students' evaluation of participation in the reflective learning group highlighted that participation had given them 'a voice' and that they felt more prepared and empowered for the transition to professional practice.

The studies above suggest that for the development of skills needed at work it is important to design learning environments where students actively engage in problem solving and integrate theoretical and practical knowledge. Thus, educational practices such as problem-based learning, project studies, integration of work-based and school-based learning, and other types of work-related learning and activated instruction are arguably conducive to development of working life skills, and hence as Newton's study evidenced may decrease feelings of inadequate knowledge and skills. Especially important here is to arrange students' possibilities to participate in authentic work communities and environments. As Filstad amd McManus (2011, p. 763, 777) state, "what is the most important for newcomers is how they become knowledgeable as they recognize that it is not their educational knowledge, but working out how to engage and participate in the social practices, that counts" ... Newcomers "find that their 'theoretical knowledge' is not the most important" but that access to social-cultural knowledge, that is, norms, values, rules and regulations - organizational culture - is vital. Indeed research on graduate nurses' transition to the workplace (Newton and McKenna, 2007; Newton, Billett and Ockerby, 2009) highlights this impact quite clearly, as the novice nurse finds learning to 'fit in' to the workplace a critical element of their transition to clinical practice. Thus, the role of partnerships between education and work seem to be significant not only from the employment point of view but also from the competences point of view.

\subsection{Decreased self-efficacy and stress}

Transitions from one phase of life to another are always considered involving the source of possible stress (Salmela-Aro, 2012). The causes of stress of newcomers seem to be quite similar to what is typically found in older workers, such as social stressors, cooperation problems and quantitative overload (e.g. Grebner et al., 2004). In particular, in professional fields involving high personal input, quickly changing situations, and socially and psychologically challenging relationships, the early career experiences may be psychologically and socially overwhelming. For example, in the field of nursing Duchscher (2009) has 
described transition shock as the experience of moving from the known role of a student to a less familiar role of professionally practicing nurse. Typical of this experience is a contrast between the relationships, roles, responsibilities, knowledge, and performance expectations required within the academic environment to those required in professional practice setting. The transition shock involves emotional, physical, socio-cultural, socio-developmental, and intellectual aspects. Emotionally, it manifests itself as extreme sensitivities, seeking validation and reassurance, fears of failure and incompetence, and so on. Physically, it may cause exhaustion, sleeplessness, poor nutrition and lack of exercise, for example. Socio-developmental aspects include role uncertainty, inadequate guidance and intergenerational dynamics (Newton et al., 2009) and intellectual aspects are related, among other things, to incongruences between theory and practice, lack of knowledge on transition, limited practical knowledge, and professional role-relations immaturity. In a current study being undertaken by Newton and colleagues on workplace learning in nursing in Australia, these aspects of incongruences are illustrated by a new graduate, Pink who was six months into her first year as a qualified nurse, reported:

I feel quite daunted and really questioning yourself and what you've learnt... you realize you rely on your senior staff a lot more than you thought you would and really there is still so much to learn.... Since becoming a graduate I see things I'm not sure about and I have to go back to the theory to look it up....I'm still observing other people learning how to do things and seeing what they're doing and I might try that next time.....I'm sort of still learning my way around things and so my autonomy is not there yet... It feels so surreal having to supervise a student; it's such a strange feeling... Sometimes I feel I shouldn't have to supervise a student, some days it's like the student and I have to sort of navigate it together.

Similarly to nursing, the early phase of teachers' career is often characterized by lowered professional self-confidence and self-efficacy as well as stress and burnout symptoms. For example, in their study Woolfolk Hoy and Burke Spero (2005) observed significant increases in self- efficacy during student teaching but significant declines during the first year of professional teaching. In a study among university teachers by Postareff et al. $(2007,2008)$, it was found that teaching-related self-efficacy among teachers who had taken few pedagogical courses was lower than among teachers who did not have pedagogical training at all. Those who had acquired more pedagogical training reported highest selfefficacy scores. Fives and her colleagues (2007) found that stress symptoms (which they called "burnout") increased and self-efficacy decreased during the first teaching practice period among student teachers, but in the long run significant increases in self-efficacy and decreases in stress symptoms were found. On the basis of these findings, it can be assumed that in the first phases of pedagogical training and teaching career teachers become aware of their personal weaknesses or learning needs, leading to decrease in self-confidence and self-efficacy. Along with the increase of experience over the years, selfefficacy expectations increase as well.

The findings described above suggest that in the early phases of professional career, in any field requiring high level expertise, there is a clear need for support systems. In the fields such as teaching and medicine there is a long tradition of mentoring being used as a support system for newcomers. Fives et al. (2007) found that student teachers experiencing high levels of guidance reported higher levels of self-efficacy for instructional practices than did those who reported less guidance. Similarly, studies on the relationship between mentoring and stress at the workplace suggest that close interaction between the younger colleague and the mentor has a potential of decreasing stress and increasing self-confidence (Thomas \& Lankau 2009; see also Aspfors et al. 2012).

As to mentoring and related support systems, the role for partnerships can provide an avenue for reducing the stressors of decreased self-efficacy and increased stress as students' transitions to their professional role and workplace. For example, in Finland there is a nationwide network for organizing mentor training, peer-group mentoring, and other forms of teacher induction support (http://www.osaavaverme.fi/eng). 
The network is coordinated by the Finnish Institute of Educational Research by the University of Jyväskylä, and the members include all teacher education units in Finland. Furthermore, among other stakeholders, national teachers' organization, Trade Union of Education in Finland, and national employers' organization, representing the biggest employer group of teachers, Local Government Employers, are active participants of the network. Within these collaborative partnerships it has been possible to develop and disseminate a new form of mentoring called peer-group mentoring. While traditional one-to-one mentoring has mainly focused on unidirectional transmission of knowledge from an experienced colleague to a younger one, peer-group mentoring is based on knowledge sharing in a group. The mentor is still usually a more experienced colleague, but the interaction and relationship between the mentor and group participants is dialogical and reciprocal (Heikkinen, Jokinen \& Tynjälä, 2012). Without the national network involving teacher education departments, national labor market partners and other stakeholders, it would not have been possible to disseminate nationwide this new form of support system for newly qualified teachers. Thus, this network is a good example of the power of partnerships.

Another successful example of a partnership model, that in this case utilized preceptorship, is one implemented between a university and a healthcare organization to enhance the transition of novice nurses to the workplace and reduce the transition shock described earlier in this section. The preceptorship model has been widely adopted in the United Kingdom, Australia and North America and is designed to increase collaboration between tertiary institutions and healthcare settings (Ockerby, Newton, Cross and Jolly, 2009). In this model, a preceptor who is a qualified nurse is assigned to work alongside a student nurse for the duration of the student's clinical placement. Research undertaken to examine this preceptorship model, between one tertiary healthcare facility in Melbourne, Australia in partnership with a school of nursing and midwifery from a major university; found that this partnership fostered the development of the students' competence through the continuity of returning to the same healthcare facility (Newton, et al. 2011).

In this particular project, second and third year undergraduate nursing students, 20 of whom were in their second year of study and eight were in their third year, were followed for a period of two years. During this time, the student informants were interviewed on five occasions. The students' age ranged from 18 55 years with a mean age of 29.5 years. The participants' fifth interview, by which time they were either engaged in or had recently completed their graduate year (i.e. the first year as a registered nurse); and included questions about the contributions of clinical placement experiences and the support provided by preceptors to participants' perceived work-readiness is drawn upon, to illustrate the outcomes of this partnership. The fifth interview also included a quantitative component comprising of four key questions, using a 5 point Likert scale ranging from 'not at all' to 'extremely' that sought participants' responses regarding: the effectiveness of the preceptorship model, the extent to which the participants felt 'work ready' at the end of the program, the extent to which their clinical experiences facilitated work readiness, and the effectiveness of preceptorship for work readiness. Ninety per cent of the students indicated a very positive response to this preceptorship model rating the program as 'very' or 'extremely' effective. More than half of the students reported 'very' or 'extremely' work ready at the completion of their degree and a similar proportion indicated that their clinical experiences prepared them 'very' or 'extremely' well to become a nurse. The nurses reported that their transition to work was enhanced through having familiarity of the organisation, as Amy, a newly graduated nurse noted:

I'm already familiar with the hospital, I don't need to learn about the paperwork, I don't need to learn about how the shift runs and, like what time the shifts start and finish, when the breaks are, um, how to do certain procedures, whether you need one nurse for a procedure or you need two.

Having this familiarisation with the actual organisational structure, reduced the nurses' stress and generated a degree of confidence amongst this group of new graduates and created a sense of continuity for them in their transition from student to new graduate worker. The nurses articulated that they did not 
feel, "so much like a fish out of water". This type of partnership model also fostered the important element of social participation which contributed to the new graduates' overall sense of work-readiness. The graduates recounted a sense of belongingness to the workplace when they were greeted by healthcare workers they had met or worked with during a clinical placement as a student. These 'familiar faces' within the workplace who acknowledged the participants generated an awareness of belongingness and being a part of a healthcare organisation. This point is illustrated by Marissa, a new graduate undertaking her first work placement at the healthcare facility where she had participated in the preceptorship model as a student nurse: It also is wonderful to be able to walk into the hospital every day and you walk in every day and people greet you. You have this sense of belonging”. This type of partnership model appears to enhance the social practice knowledge that individuals require to effectively engage in practice and further learning (Eraut, 2004).

Research on graduate nurses' transitions (Andersson \& Edberg, 2010; Newton \& McKenna, 2007) found that the most influencing factors for new graduates to gain confidence in their skills was the support provided in the workplace through their relationships with colleagues. Clearly such a partnership model, as this preceptorship model, enables the transition from student to worker a smoother passage, reducing the stress and enhancing the graduates' self-efficacy. Indeed, Korte and Lin (2013) found that for newcomers entering a work organisation that their levels of confidence was facilitated by the quality relationships and good mentoring offered to them. All of this points to the salience of partnerships in providing supportive educational experiences.

\subsection{Instability of occupational identity, early attrition, and changing occupation}

Occupational identity in the early phase of one's career is often weak, and young people may change their vocational field while actually studying a vocation. Dropping out from education is usually seen as a risk factor for remaining without any qualifications, unemployment and marginalization. However, it can also be seen as an opportunity for improving future prospects by opening possibilities for education in some other field that young people may experience more attractive. For example, Schmid and Stalder (2012) followed 1300 Swiss young people who had experienced an early apprenticeship contract termination and found out that about three quarters of these continued their education within three years of the contract termination, and that the majority of them already resumed their education in the first month.

Furthermore, these occupation changers were happier with their new education than with the previous one.

The issue of early attrition in health care, particularly among nursing, remains obstinately resistant despite significant efforts of government and employers. In exploring the premises of becoming a nurse Billett, Newton and Ockerby (2010) found that diverse pathways were taken by individuals in pursuing nursing as an occupation. Billet et al. (2010) presented illustrative data of nine student nurses from a subset of 28 student nurses who had participated in a longitudinal, multi-method investigation on workplace learning in nursing, in Australia. Individuals' pathways into nursing were either from direct school or from their experiences in which they had observed and came to appreciate nursing work. The informants shared that they had either undertaken care-related activities as part of their secondary schooling; volunteer community work in an aged care home having been previously expelled from school; as an option to secure employment and salary; commenced a higher status health related degree (physiotherapy) and changed to nursing; to caring for elderly parents. In a small follow-up study in 2010, Newton interviewed nursing students from the United Kingdom (UK) and America to ascertain if these types of occupational pathways into nursing were reflected elsewhere. Similar stories emerged with the students in these countries sharing accounts of always wanting to be a nurse to entering the occupation through association 
with a caring experience or incidence, as Ruth from the UK, a third year student at the time of the interview, illustrates this with a change in occupation as well:

Entering nursing was a complete surprise for me. I went into nursing at 26 years of age having studied art for four and half years. It wasn't till I got pregnant and I just loved interacting with nurses and thought what a lovely job it is... you're with people at the most vulnerable times; it's such a privilege position to be in and to be part of it...

Prior to her change in occupation, Ruth had worked as a resident artist in schools and the community. Another student, Francis from America indicated that nursing was not always something that she had initially intended to do. She had spent her first three and half years after leaving school working as a customer representative in a hospital and then worked as nanny for two years. The prospect of the diversity of fields of nursing that a nurse can pursue a career in, led her to thinking about going to university.

The early phase of an individual's working career seems to be critical for attrition or retention. Early attrition has been widely examined in teachers' profession although research shows that attrition rates in teaching are not higher than in other professions that require comparable levels of education. For example, in a study by Harris and Adams (2007) turnover rate was about $15 \%$ in social work, $8 \%$ in accounting, $8 \%$ in teaching, and $6 \%$ in nursing. However, there are differences between the years of experience in attrition rates. According to the report by OECD (2005), younger teachers are more likely to leave the teachers' job than more experienced teachers. As the main reason for leaving, the report mentions poor working conditions. These may be related to workload, lack of support, student behavior and relationships with parents. Findings by Hong (2010) also showed that pre-service teachers tended to have naïve and idealistic perceptions of teaching. This finding suggests the need for more practice and real-life work experience during teacher education and training may be needed. This might also apply to other practice based professional field as well.

The issue of vocational school dropouts and occupation changes raises the question of the functioning of career guidance provision. Experts in the field of career guidance have argued for expansion of the guidance paradigm because the everyday field of guidance has changed (Sultana 2004; OECD, 2004). One example of this paradigm change is seeing guidance as part of a wider horizontally and vertically networked support system of the society. For instance, Nykänen and her colleagues (2012) have introduced a model in which schools, social, health, and public employment services jointly design, implement and evaluate regional guidance services. In this way, the networked partnerships may provide tailored and timely support for individuals in every life situation. It is worthy to note that the importance of preparation for practice in choosing an occupation was first brought to our attention by Dewey (1916). He proposed that the two purposes of vocational education was supporting individuals' capacities and interests; and preparing individuals for the occupation to which they are drawn too. Given our rapidly changing world, and from the examples offered from the studies on nursing students, it would seem that it is not only young people, but also more experienced people who may need support while looking for their future field of study and work. Consequently, requirements for supportive arrangements may be far more widespread than just for 'newcomers'.

\subsection{Newcomers' role and position in a work community, and the importance of workplace learning}

Hakkarainen et al. (2004, p.145) have pointed out that typical of many communities of practice in contemporary workplaces is asymmetric distribution of knowledge and competence: Old-timers' knowledge is mostly valued and transmitted to newcomers who, again, are supposed to adjust to existing working culture and practices. In one of the first author's in-service training sessions a young teacher 
described this situation as follows: "New teachers with their new ideas will be suppressed in less than a year”. Many studies on novice teachers' work challenges have confirmed these experiences. For example, in a study by Shoval et al. (2010) among novice physical education teachers it was found that very often new teachers suffer from a gap between their initiatives and the environments' lack of appreciation. Similarly, Saka et al. (2009) have reported a case study illustrating a situation where a reform-minded novice teacher moves away from his goals of reform and compromises his earlier willingness to significantly contribute to the school context (see also, Maynard 2001). Naturally, these kinds of experiences of ignoring newly qualified professionals' skills and knowledge are not restricted to teachers’ profession only but are common among new employees in any field.

Some newcomers' support systems explicitly address the need of enhancing beginners' engagement. For example, the study by Saks and Gruman (2011) represents a traditional approach where newcomers' induction into a workplace is conceptualized as a socialization process. The purpose of this process is to get newcomers adjust to their new workplace and learn the behaviors, attitudes, and skills necessary to fulfill their duties and act as an active a member of the organization. In their study, Saks and Gruman (ibid.) found that institutionalized socialization tactics involving structured, formalized and fixed forms of support was positively related to newcomers' perceived person-job and person-organization fit as well as emotions and self-efficacy. Furthermore, they were indirectly related to newcomer engagement. Similar findings have also been recently reported by Simosi (2012) and Korte and Lin (2013) who found that perceived organizational support, supervisory support and colleague support influences transfer of training and commitment towards organization.

An alternative to the concept of socialization of newcomers into existing practices is presented by Wang and Odell (2007) who have analyzed models on the background of one of the most popular way of supporting new workers, mentoring. They make a distinction between three approaches to mentoring: 1) humanistic perspective emphasizing the development of newcomer's self-esteem and confidence, 2) situated apprentice perspective focusing on newcomers' adjustment to the prevailing culture of practice (and, thus, representing the above mentioned socialization view), and 3) critical constructivist perspective supporting critical outlook towards existing practices and structures, and developing reform-oriented mindset and collaborative knowledge transformation cultures. The last mentioned perspective could be seen as part of an organizational culture that Hakkarainen and his colleagues (2004) call "innovative knowledge communities". Typical of these communities is intentional pursuit of creating new knowledge and practices, open communication, networking, and knowledge sharing. The distribution of knowledge is symmetric and heterogeneous, meaning that not only old-timers' but also newcomers' knowledge is valued and utilized, and their fresh insights are heard and taken seriously in developing practices. Rubin (2009) refers to the concept of collaborative leadership as a form of leading the communal learning processes aiming at these kinds of practices. When this idea is applied into guidance provision discussed earlier, guidance personnel takes multi-professional responsibility for students' learning and education with actions promoting the practices, strategies and structures that support students' transition from one educational level to another or to working life (Jäppinen, 2012).

Common to the ideas of innovative knowledge communities, professional learning communities, and collaborative leadership is that individuals' agency is supported in social communities. As Billett (2004) has described learning at work is mediated by both the contributions of workplaces and individual's agency. This same pattern was found to apply to studies of students' transitions from school (Billett,et al 2012). How individuals participate and interact in their workplace is central to their learning. But this is not enough. As the newcomers' experiences of suppressing their ideas described above show it is not only in the individuals' hands in how they learn and proceed in their job and career. The quality of learning depends also on the workplace affordances. Thus, in Billett's (2004) terms, learning at the workplace is reciprocally constructed in co-participatory practices where individuals elect how to engage in and learn from what workplaces afford them. These set of factors also played across accounts of school students to 
post-school life and extended to whether and how they elected to remain in educational programs or withdraw from them. Returning to the Australian study on the preceptorship model in nursing (see section 2.3) the development of the this co-participatory practice is illustrated through this longitudinal investigation of nursing students' transition to practice from student to qualified nurse and how the role of the registered nurse, who was the preceptor, influenced the novice's engagement in learning. The value of this partnership model as a developmental model for supporting competences resides in the close guidance provided by the more experienced practitioner to the novice. This is an important element of learning for health professional students as they adapt the teachings from the academic setting and make situational adjustments to the clinical environment under the guidance of their preceptor (i.e. a registered nurse). Preceptors' interest in engaging with novices and actively seeking out learning opportunities is also fundamental to the productive engagement of the novice (Newton et al., 2011). Whilst preceptors might provide diverse learning experiences in the workplace, students, in this particular study, recognised and valued that engagement in learning opportunities is a reciprocal process. For example Stef, a $3^{\text {rd }}$-year student, pointed out that not only did one need preceptors who were: 'interested in and willing to help you learn' but that it was also important for her to engage with the opportunities provided: 'I think it's a two way street.'

The preceptors also acknowledged that in undertaking this role it was an avenue for enhancing their own clinical knowledge as they learnt alongside their students. For example Rose, a preceptor, reported: 'sometimes when they [students] ask something or they query something, I have to go and look it up too which I don't mind doing because that also shows up what you know and don't know.' This willingness to engage in a preceptoring partnership is an essential component of learning in the workplace as Ben, a $2^{\text {nd }}-$ year nursing student, commented: 'preceptoring is everything... a good preceptor can make or break a clinical placement.' Zilembo and Monterosso (2008) suggest that effective preceptors are those who exhibit characteristics that include being competent, organised, supportive, motivating, and approachable with strong interpersonal skills. Thus engagement in learning through preceptorship is premised on a reciprocal process. This process, however, is augmented for novice nurses if their preceptors relate to them as individuals and realize the novice's personal knowledge and skill level. Participants in this study by Newton et al. (2011) identified the importance of preceptors being familiar with a range of learning styles, and recognising novices as unique individuals. As Jayne, during her second year as undergraduate student nurse, pointed out that it is important that preceptors acknowledge: 'each student as an individual in deciding what they can and can't do, recognising a person as someone unique.' Whilst understanding the variations in individual novices' learning needs might generate more work in supporting and guiding them, Polly, an experienced preceptor, explained that, being a preceptor is: 'about allowing somebody to, to find their own way but guide them safely.' An example of the guidance experience sought by students was described by Clare, during her third year as an undergraduate student, when learning two new skills:

When you are doing things like taking blood or doing an ECG, what I find helpful is a good preceptor, when I do the skill for the first time that I can be shown it and then I do it and that someone [the preceptor] is with me. That makes a big difference.

In her current research on workplace learning whilst undertaking fieldwork on a medical ward at a regional hospital in Victoria, Australia, Newton observed what she considered exemplary guidance by a preceptor, Sumi, to her second year undergraduate nursing student. A description of the event is below:

[At the nurse's work station] The patient is due for a daily injection. Sumi gives the student an explanation about the generic name of the injection drug and where to locate the drug order on the patient's medication chart. She questions her student on where she'll give the injection, seeking information from the student about what she has been taught at the university about giving this particular type of injection. Sumi provides detailed instructions including the underlying pathology on where to locate the injection making sure the student is aware of the 
need to alternate injection sites, avoiding anywhere that the might be pressured by clothing elastic. [Sumi and the student move to patient's bedside] Sumi guides the student as the student gives the injection, offering a calming voice "nice and steady" she says to her student. Sumi then directs the student to sign the patient's medication chart with her and make sure the patient is left comfortable position to have her breakfast. Sumi then checks that her student is okay, 'how did that feel?' She reassures her student that she did a great job.

This guidance by more experienced co-workers certainly can assist in developing the kinds of knowledge and skills required for expert performance. However, as identified above it needs to be recognised as a reciprocal process of participation by both the guide and the learner (Billett \& Newton, 2009). Students in the preceptorship model study did not always experience a facilitative guided learning environment. An experience shared by Eddie, when she was a second year undergraduate nursing student, she recounted an occasion when: "I walked into the handover room (i.e. a room where nurses at the end of a shift pass on information to the on-coming shift of nurses) and sat down and not a word was said to me. It was very hard, coming into an established team and they'll all know each other and have their way of doing things...” This situation was particularly challenging for Eddie, for despite having prior experience as an enrolled nurse and being a mature-age student, she felt quite intimidated by the nursing staff during her clinical placements.

The invitational qualities of the workplace are pivotal in enhancing the translation of learning from school to work. Experienced practitioners, Newton et al. $(2011,48)$ contend "need to be aware of providing appropriate and challenging learning opportunities and be flexible in allowing novices to experience different procedures and to practice skills themselves". Studies on workplace learning have shown that there are big differences between the workplaces in how and what kind of learning opportunities they offer for their employees' learning and professional development (Tynjälä 2008, 2013) and this variance can be seen in the examples offered from the studies presented in this chapter in nursing. Fuller and Unwin (2004) have made a distinction between what they call expansive and restrictive approaches to workforce development, the former representing an environment where people have plenty of opportunities to participate in diverse activities and communities of practice, while the latter describes workplaces that offer limited opportunities for learning. Certainly, the experience Eddie recounted above was one of a restrictive environment yet had the potential to be a rich pedagogical opportunity. The nursing shift handover can provide a learning moment for all the practitioners who are at different levels of competence, offering insights into nursing practices (Billett \& Newton, 2010). An expansive workplace arranges time for reflection and opportunities for boundary crossing, uses managers as facilitators, values innovation and offers people chances to learn new jobs and skills, while restrictive workplaces tend to rely on old practices and do not seek innovation. However, beyond what Fuller and Unwin (2004) propose about the different qualities of workplace settings, it is also necessary to include how individuals elect to engage in those environments. As Billett (2004) has shown even the most expansive of workplaces can be rendered restrictive if individuals elect not to engage in them and the most restrictive can be render rich learning environments if learners act agentically. All of this emphasizes the importance of considering not only the two environments, but also the relations and interdependencies between them..

\section{Conclusions}

In this chapter, we have examined transition from education to working life as a critical phase in the development of professional competence. We have identified several challenges that newly qualified people meet when entering the world of work. The examination revealed that school-to-work transition is not only a young person's individual movement from one place to another but a part of individual, social and institutional process where individuals' learning needs and environments' requirements and 
circumstances meet each other. Transitions are influenced by individuals' cultural knowledge and expectations of others, their positioning within the organization and the opportunities afforded to themt (Fenwick, 2013), and also how learners elect to engage in these environments. Therefore, because transitions are practices that involve individuals making decisions about how they engage and for what purposes it is important to consider not just social practices of the settings, but also how individuals engage in them.

Transitions in human life cycle are phases when susceptibility to stress may increase. Finishing schooling brings about concern over employment and adjustment to a new working environment. Individuals may experience decreased self-efficacy and feel their skills and knowledge inadequate. Sometimes young people's expectations of the occupation or job have been unrealistic, or their identity development has been in such turbulence that they may find themselves as in a totally wrong line of work.

These kinds of challenges of newly qualified workers and professionals may give a quite dark picture of the transitions from school to work. However, there is another side as well. There are several ways to smooth over the problems and setbacks in the transitional phase, and here the role of social partnerships is crucial. Our analysis cautiously suggested that in countries where vocational education and training is based on apprenticeship training or includes a considerable amount of workplace learning the threat of unemployment after qualifications is smaller than in countries with a strictly school-based education. Partnerships may also be used in organizing induction support systems such as mentoring as was the case in the Finnish education system or through preceptorship as illustrated in nursing. Furthermore, lifelong guidance systems have been recently developed based on multi-professional networking between schools, social, health and public employment services in order to provide tailored and timely support in transition in any phase of a life cycle. Altogether, it seems that different forms of partnerships may play an important role in paving the way to smooth transitions and securing continuous professional competence development. At the same time these partnerships not only help individuals but they also may serve the development of vocational practice. However, the challenge in determining if partnerships assist in enabling a 'successful' transition are difficult to determine due to the complex interplay of the myriad of educational, sociocultural and material relations that need to be considered.

\section{References}

Andersson, P. L., \& Edberg, A. (2010). The transition from rookie to genuine nurse: narratives from Swedish nurses 1 year after graduation. The Journal of Continuing Education in Nursing, 41(4), 186192.

Aspfors, J., Hansén, S-E, Tynjälä, P., Heikkinen, H.L.T., \& Jokinen, H. (2012). Lessons learnt from peergroup mentoring experiments. In H.L.T. Heikkinen, H. Jokinen \& P. Tynjälä (eds.) Peer-group mentoring for teacher development (pp. 131-143). London: Routledge.

Betti, G., Lemmi, A. \& Verma, V.(2005). A comparative analysis of school-to-work tranistions in European Union. Inovation 18(4), 419-442.

Billett, S. (2004). Learning through work: Workplace participatory practices. In H. Rainbird, A. Fuller \& A. Munro (Eds.), Workplace learning in context (pp. 109-125). London: Routledge.

Billett, S., Johnson, G., Thomas, S., Sim, C., Hay, S \& Ryan, J (eds.) (2012) Experiences of school transitions: Policies, practice and participants Dordrecht: Springer.

Billett, S. \& Seddon, T. (2004). Building community through social partnerships around vocational education and training. Journal of Vocational Education and Training 56 (1), 51-67.

Billett, S., Newton, J. M. \& Ockerby, C. (2010) Becoming a nurse: Premises for selecting and engaging in an occupation. Studies in the Education of Adults (42) 1 pp. 47-62. 
Billett, S \& Henderson, A. (2011) Promoting professional learning: Integrating experiences in university and practice settings. Dordrecht: Springer.

Crebert, G., Bates, M., Bell, B., Patrick, C-J., \& Cragnolini, V. (2004). Ivory tower to concrete jungle revisited. Journal of Education and Work, 17(1), 47-70.

Deitmer, L. \& Heinemann, L. (2009). Evaluation approaches for workplace learning partnerships in VET: Investigating the learning dimension. In M-L. Stenström \& P. Tynjälä (eds.) Towards integration of work and learning. Strategies for connectivity and transformation (pp.137-151). Dordrecth: Springer.

Dewey, J. (1916) Democracy and Education. New York: The Free Press

Duchscher, J.E.B. (2009). Transition shock: the initial stage of role adaption for newly graduated registered nurses. Journal of Advanced Nursing 65(5), 1103-1113.

Eraut, M.( 2004) Informal learning in the workplace. Studies in Continuing Education 26 (2), 247-273.

European Commission (2012). Employment and social developments in Europe 2011. DirectorateGeneral for Employment, Social Affairs and Inclusion Directorate A. Manuscript completed in November 2011.

http://ec.europa.eu/social/main.jsp?catId=113\&langId=en\&pubId=6176\&type=2\&furtherPubs=yes

European Union (2012). http://epp.eurostat.ec.europa.eu/portal/page/portal/eurostat/home/

Feltovich, P. J., Prietula, M. J., \& Ericsson, K.A. (2006). Studies of expertise from psychological perspectives. In K. A. Ericsson, N. Charness, P. J. Feltovich \& R. R. Hoffman (Eds.) The Cambridge handbook of expertise and expert performance (pp. 41-67). Cambridge, NY: Cambridge University Press.

Fenwick, T. (2013) Understanding transitions in professional practice and learning Journal of Workplace Learning, 25 (6), 352-367

Fives, H., Hamman, D., \& Olivarez, A. (2007). Does burnout begin with student teaching? Analyzing efficacy, burnout and support during the student-teaching semester. Teaching and Teacher Education, 23, 916-934.

Filstad, C. \& McManus, J. (2011). Transforming knowledge to knowing at work: The experiences of newcomers. International Journal of Lifelong Education 30 (6), 763-780

Fuller, A., \& Unwin, L. (2004). Expansive learning environments. Integrating organizational and personal development. In H. Rainbird, A. Fuller \& A. Munro (Eds.), Workplace learning in context (pp. 126144). London: Routledge.

Grebner, S., Elrefing, A., Semmer, N.K., Kaiser-Probst, C. \& Schlapbach, M-L. (2004). Stressful situations at work in private life among young workers: An event sampling approach. Social Indicators Research 67 (1/2), 11-49.

Guile, D. 2009. Conceptualising the transition from education to work as vocational practice: Lessons from the UK's creative and cultural sector. British Educational Research Journal 35(5), 761-779.

Hakkarainen, K., Palonen, T., Paavola, S., \& Lehtinen, E. (2004). Communities of networked expertise: Professional and educational perspectives. Amsterdam: Elsevier.

Harris, D. N., \& Adams, S. (2007). Understanding the level and causes of teacher turnover: A comparison with other professions. Economics of Education Review, 26, 325-337.

Harris, M., Chisholm, C. \& Allan, M. (2010). Lifeplace learning for effective professsional development in industry and business. Industry and Higher Education, 24(2), 135-141.

Heikkinen, H., Jokinen, H., \& Tynjälä, P. (eds) (2012). Peer-group mentoring for teacher development. London: Routledge.

Hong, J. Y. (2010). Pre-service and beginning teachers' professional identity and its relation to dropping out of the profession. Teaching and Teacher Education, 26, 1530-1543.

Jäppinen, A-K. (2012). Transitions in individual vocational education pathways: challenges and collaborative solutions. In P. Tynjälä, M-L. Stenström \& M. Saarnivaara (eds.) Transitions and transformations in learning and education (pp. 103-116). Dordrecht: Springer.

Jäppinen, A.-K. (2010). Preventing early leaving in VET: Distributed pedagogical leadership in characterising five types of successful organizations. Journal of Vocational Education and Training, 62(3), 297-312. 
Koen, J. Klehen, U-C, \& van Vianen, A.E,M.(2012). Training career adaptability to facilitate successful school-to-work transition. Journal of Vocational Behavior 81(3), 395-408.

Korte, R. \& Lin, S. (2013) Getting on board: Organizational socialization and the contribution of social capital. Human Relations 66(3), 407 -428

Livanos, I. (2010). The relationship between higher education and labour market in Greece: the weakest link? Higher Education, 60, 473-489.

Maynard, T. (2001). The student teacher and the school community of practice: a consideration of 'learning as participation'. Cambridge Journal of Education, 31(1), 39-52.

Moreau, M., \& Leathwood, C. (2006). Graduates employment and the discourse of employability: A critical analysis. Journal of Education and Work, 19(4), 305-324.

Murtonen, M., Olkinuora, E., Tynjälä, P., \& Lehtinen, E. (2008). "Do I need research skills in working life?": University students' motivation and difficulties in quantitative methods courses. Higher Education, 56(5), 599-612.

Newton, J.M. (2011) Reflective learning groups for student nurses IN Billett, S \& Henderson, A. Promoting professional learning: Integrating experiences in university and practice settings. Springer: Dordrecht, The Netherlands. ISBN: 978-90-481-3936-1

Newton, J. M., Billett, S. \& Ockerby, C. (2009) Journeying through clinical placements: An examination of six student cases. Nurse Education Today 29, p 630-634

Newton, J.M. and McKenna, L. (2007) The transitional journey through the graduate year: A focus group study, International Journal of Nursing Studies, 44(7): 1231 - 37

Nykänen, S., Saukkonen, S. \& Vuorinen, R. (2012). Transformations in lifelong guidance provision. In P. Tynjälä, M-L. Stenström \& M. Saarnivaara (eds.) Transitions and transformations in learning and education (pp. 187-202). Dordrecht: Springer.

OECD. (2000) From initial education to working life. Paris: OECD.

OECD. (2004). Career guidance: A handbook for policy makers. Paris: OECD.

OECD. (2005). Teachers matter: Attracting, developing and retaining effective teachers. Paris: OECD.

OECD (2012). http://www.oecd.org/std/labour-stats/HUR NR10e12.pdf

Ockerby, C., Newton, J. M., Cross, W. M. \& Jolly, B. (2009). A learning partnership: Exploring preceptorship through interviews with registered and novice nurses. Mentoring and Tutoring: Partnership in Learning 17(4) November 353 - 368

Postareff, L., Lindblom-Ylänne, S., \& Nevgi, A. (2007). The effect of pedagogical training on teaching in higher education. Teaching and Teacher Education, 23, 557-571.

Postareff., L., Lindblom-Ylänne, S., \& Nevgi, A. (2008). A follow-up study of the effect of pedagogical training on teaching in higher education. Higher Education, 56, 29-43.

Rubin, Hank (2009). Collaborative Leadership: Developing Effective Partnerships for Communities and Schools. Corwin Press.

Saka, Y., Southerland, S. A., \& Brooks, J. (2009) Becoming a member of a school community while working toward science education reform: Teacher induction from a cultural historical activity theory (CHAT) perspective. Science Education, 93, 996-1025.

Saks, A.M. \& Gruman, J.A. (2011). Getting newcomers engaged: the role of sozialization tactis. Journal of Managerial Psychology 26(5), 383-402.

Salmela-Aro, K. (2012). Motivation, burnout, and engagement during critical transitions from school to work. In In P. Tynjälä, M-L. Stenström \& M. Saarnivaara (eds.) Transitions and transformations in learning and education (pp. 153-168). Dordrecht: Springer.

Schmid, E. \& Stalder, B.E. (2012). Droppping out from apprenticeship training as an opportunity for change. In P. Tynjälä, M-L. Stenström \& M. Saarnivaara (eds.) Transitions and transformations in learning and education (pp. 117-130). Dordrecht: Springer.

Shoval, E., Erlich, I. \& Feijgin, N. (2010). Mapping and interpreting novice physical education teachers“ self-perceptions of strenghs and difficulties. Physical Education and Sport Pedagogy, 15(1), 85-101. 
Simosi, M. (2012). Disentangling organizational support construct: The role of different sources of support to newcomers' training transfer and organizational commitment. Personnel Review, 41 (3), 301-20.

Stajkovich. A \& Luthans, F. (1999). Self-efficacy and work-related performance. A meta-analysis. Psychological Bulletin124 (2), 240-261.

Sultana, R. (2004). Guidance policies in the knowledge society. Trends, challenges and responses across Europe (CEDEFOP Synthesis Report). Thessaloniki, Greece: Cedefop.

Stenström, M.-L. (2006). Polytechnic graduates working life skills and expertise. In P. Tynjälä, J. Välimaa \& G. Boulton-Lewis (Eds.), Higher education and working life: Collaborations, confrontations and challenges (pp. 89-102). Amsterdam: Elsevier.

Teichler, U. (2007). Does higher education matter? Lessons from a comparative graduate survey. European Journal of Education 42(1), 11-34.

Thomas, C., \& Lankau, M. (2009). Preventing burnout: The effects of LMX and mentoring on socialization, role stress, and burnout. Human Resource Management, 48(3), 417-432.

Tynjälä, P. 2013. Toward a 3-P model of workplace learning: A literature review. Vocations and Learning 6(1), 11-36.

Tynjälä, P. (2008). Perspectives into learning at the workplace. Educational Research Review, 3, 130154.

Tynjälä, P. \& Heikkinen, H. 2011. Beginning teachers' transition to working life: Theoretical perspectives and best practices. Zeitschrift für Erziehungswissenshaft 14 (1), 11-33.

Tynjälä, P. \& Gijbels, D. (2012). Changing world - changing pedagogy. In P. Tynjälä, M.-L. Stenström, \& M. Saarnivaara (eds.) Transitions and transformations in learning and education (pp. 205-222). Dordrecth: Springer.

Tynjälä, P., Heikkinen, H., \& Kiviniemi, U. (2010). Integratiivinen pedagogiikka opetusharjoittelussa. (Integrative pedagogy in teacher training). Accepted to be published in Kasvatus - Finnish Journal of Education (in Finnish).

Tynjälä, P., Räisänen, A., Määttä, V., Pesonen, K., Kaupppi, A., Lempinen, P., Ede, R., Altonen, M. \& Hietala, R. (2006a). Työpaikalla tapahtuva oppiminen ammatillisessa peruskoulutuksessa. Arviointiraportti. Koulutuksen arviointineuvoston julkaisuja 20. [Workplace learning in vocational education and training. An evaluation report. Publications from the Finnish Education Evaluation Council 20. In Finnish].

Tynjälä, P., Slotte, V., Nieminen, J., Lonka, K., \& Olkinuora, E. (2006b). From university to working life: Graduates' workplace skills in practice. In P. Tynjälä, J. Välimaa \& G. Boulton-Lewis (Eds.), Higher education and working life: Collaborations, confrontations and challenges (pp. 73-88). Amsterdam: Elsevier.

Vaatstra, R. \& Vries, R. 2007. The effect of the learning environment on competences and training for the workplace according to graduates. Higher Education 53, 335-357.

Virtanen, A., Tynjälä, P. \& Eteläpelto, A. (2012) Factors promoting vocational students' learning at work: A study on student experiences. Journal of Education and Work (iFirst Article)

Volanen, M.V. (2012). Transition and constitution in school/work relations. In P. Tynjälä, M-L. Stenström \& M. Saarnivaara (eds.) Transitions and transformations in learning and education (pp. 67-84). Dordrecht: Springer.

Vuorinen-Lampila, P. \& Stenström, M-L. (2012). Higher education graduates’ employment and the uncertainty of working life. In P. Tynjälä, M-L. Stenström \& M. Saarnivaara (eds.) Transitions and transformations in learning and education (pp. 131-151). Dordrecht: Springer.

Wang, J. \& Odell, S. (2007). An alternative conception of mentor-novice relationships: Leaving to teach in reform-minded ways as a context. Teaching and Teacher Education 23, 473-489.

White, L. (2013). Something's not working Nursing Review Issue 9, October, 10-12

Woolbers, M. H. (2000). The effects of level of education and mobility bet on employment and unemployment in the Netherlands. European Sociological Review, 16(2), 185-200. 
Woolfolk Hoy, A., \& Burke Spero, R. (2005). Changes in teacher efficacy during the early years of teaching: A comparison of four measures. Teaching and Teacher Education, 21, 343-356. 